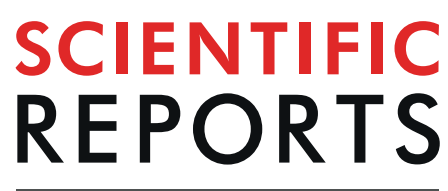

natureresearch

\title{
OPEN Diamond-inclusion system recording old deep lithosphere conditions at Udachnaya (Siberia)
}

Received: 14 May 2019

Accepted: 12 August 2019

Published online: 29 August 2019

\author{
Fabrizio Nestola ${ }^{1}$, Gabriele Zaffiro ${ }^{2}$, Mattia L. Mazzucchelli ${ }^{2}$, Paolo Nimis ${ }^{1}$, \\ Giovanni B. Andreozzi ${ }^{3}$, Benedetta Periotto ${ }^{1}$, Francesco Princivalle ${ }^{4}$, Davide Lenaz ${ }^{4}$, \\ Luciano Secco ${ }^{1}$, Leonardo Pasqualetto ${ }^{1}$, Alla M. Logvinova ${ }^{5,6}$, Nikolay V. Sobolev ${ }^{5,6}$, \\ Alessandra Lorenzetti ${ }^{7}$ \& Jeffrey W. Harris ${ }^{8}$
}

\begin{abstract}
Diamonds and their inclusions are unique fragments of deep Earth, which provide rare samples from inaccessible portions of our planet. Inclusion-free diamonds cannot provide information on depth of formation, which could be crucial to understand how the carbon cycle operated in the past. Inclusions in diamonds, which remain uncorrupted over geological times, may instead provide direct records of deep Earth's evolution. Here, we applied elastic geothermobarometry to a diamond-magnesiochromite (mchr) host-inclusion pair from the Udachnaya kimberlite (Siberia, Russia), one of the most important sources of natural diamonds. By combining $X$-ray diffraction and Fourier-transform infrared spectroscopy data with a new elastic model, we obtained entrapment conditions, $P_{\text {trap }}=6.5(2) \mathrm{GPa}$ and $T_{\text {trap }}=1125(32)-1140(33){ }^{\circ} \mathrm{C}$, for the mchr inclusion. These conditions fall on a ca. $35 \mathrm{~mW} / \mathrm{m}^{2}$ geotherm and are colder than the great majority of mantle xenoliths from similar depth in the same kimberlite. Our results indicate that cold cratonic conditions persisted for billions of years to at least $200 \mathrm{~km}$ in the local lithosphere. The composition of the mchr also indicates that at this depth the lithosphere was, at least locally, ultra-depleted at the time of diamond formation, as opposed to the melt-metasomatized, enriched composition of most xenoliths.
\end{abstract}

Cr-spinels in Diamonds. Lithospheric diamonds (those diamonds formed at depths between about 130 and $200 \mathrm{~km}$ ) represent $99 \%$ of all mined diamonds ${ }^{1}$. These diamonds may contain mineral inclusions, which can be used to derive inferences on the physical-chemical environments in which their host diamonds were formed. Cr-rich spinel (mainly magnesiochromite, hereafter, $\mathrm{mchr}$ ) is one of the most common inclusions found in diamonds, representing about $14 \%$ of reported inclusions in lithospheric diamonds worldwide ${ }^{1}$. The compositional variations in mchr inclusions are mainly reflected in their $\mathrm{Cr} /(\mathrm{Cr}+\mathrm{Al})$ and $\mathrm{Mg} /(\mathrm{Mg}+\mathrm{Fe})$ molar ratios (hereafter, $\mathrm{Cr} \#$ and $\mathrm{Mg} \#$, respectively). Typical ranges are $\mathrm{Cr} \#=0.80-0.93$ and $\mathrm{Mg} \#=0.59-0.80$, with an average crystal chemical formula of $\mathrm{Mg}_{0.70} \mathrm{Fe}_{0.36} \mathrm{Cr}_{1.67} \mathrm{Al}_{0.26} \mathrm{O}_{4}{ }^{1}$. The composition of mchr in mantle peridotites from the diamond stability field depends on pressure $(P)$, temperature $(T)$, host-rock composition and modal abundance of mchr in the rock ${ }^{2}$. Since the composition of $\mathrm{mchr}$ is not a simple function of $P$ and $T, \mathrm{mchr}$ inclusions are not typically used for geothermobarometry. In this work, we adopted the elastic geothermobarometry approach to determine the formation $P$ of mchr-bearing diamonds. Given the relatively common occurrence of $\mathrm{mchr}$ inclusions in diamonds, this method can potentially be applied to a large number of stones from worldwide localities. This would in turn allow better insight into the depth distribution of lithospheric diamonds at global scale and, consequently, into the processes that control diamond formation in the Earth's mantle.

\footnotetext{
${ }^{1}$ Dipartimento di Geoscienze, Università degli Studi di Padova, Via Gradenigo 6, I-35131, Padova, Italy. ${ }^{2}$ Dipartimento di Scienze della Terra e dell'Ambiente, Università degli Studi di Pavia, Via Ferrata 1, I-27100, Pavia, Italy. ${ }^{3}$ Dipartimento di Scienze della Terra, Sapienza Università di Roma, Piazzale Aldo Moro 5, I-00185, Roma, Italy. ${ }^{4}$ Dipartimento di Matematica e Geoscienze, Università degli Studi di Trieste, Via Weiss 8, I-34127, Trieste, Italy. ${ }^{5}$ Institute of Geology and Mineralogy, Russian Academy of Sciences Siberian Branch, Novosibirsk, 630090, Russia. ${ }^{6}$ Department of Geology and Geophysics, Novosibirsk State University, Pirogova 2, 630090, Novosibirsk, Russia. ${ }^{7}$ Dipartimento di Ingegneria Industriale, Università degli Studi di Padova, Via Marzolo 9, I-35131, Padova, Italy. ${ }^{8}$ School of Geographical and Earth Sciences, University of Glasgow, Glasgow, G12 800, UK. Correspondence and requests for materials should be addressed to F.N. (email: fabrizio.nestola@unipd.it)
} 


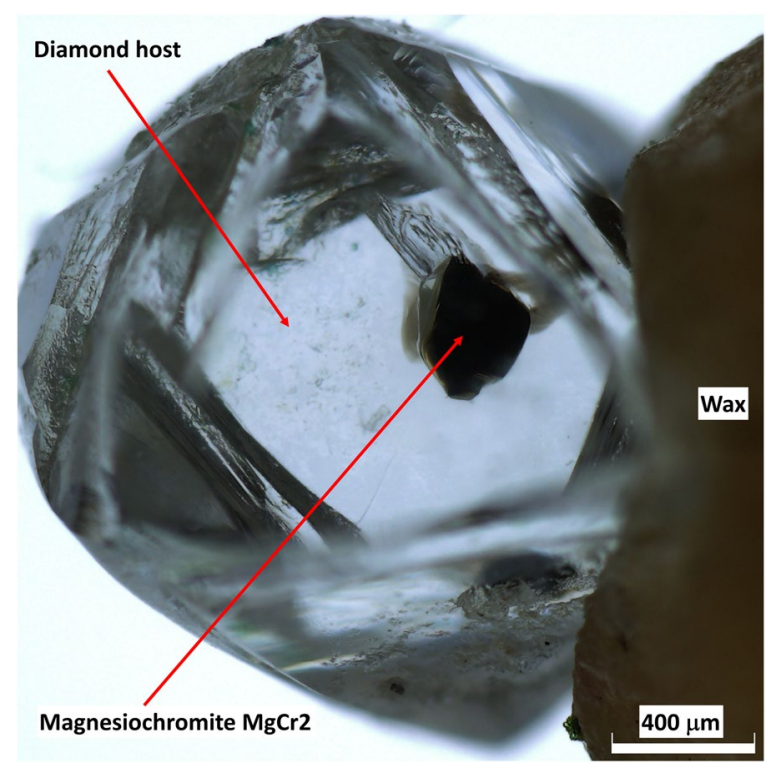

Figure 1. MgCr2 inclusion still trapped within its diamond host, mounted on wax for SC-XRD measurements.

Unprecedented Application of Elastic Geothermobarometry to Diamond-mchr host-Inclusion System. The elastic geothermobarometry approach is based on an old idea ${ }^{3,4}$; in the last few years, its theoretical basis has been extended with the aim to calculate the depth of formation of a diamond-inclusion pair, by combining non-linear equations of state (EoS) with suitable models for elastic relaxation and without any approximations of linear elasticity ${ }^{5-17}$. When a mineral trapped in a host at conditions $P_{\text {trap }}$ and $T_{\text {trap }}$ is exhumed to the Earth's surface, it may develop residual strains as a result of the contrast in elastic properties between the host and the inclusion. If these residual strains are measured when the host is at room pressure, and $T_{\text {trap }}$ is known independently, $P_{\text {trap }}$ can be back-calculated as the conditions at which there are no strain and stress gradients in the host-inclusion system. This calculation is possible if the elastic properties (i.e. bulk modulus, its pressure derivative and the thermal expansion behavior expressed as EoS) of both the host and the inclusion are known. So far, only the EoS for diamond and for a few common mineral inclusions in diamond were available with the accuracy required for geobarometric calculation $\mathrm{s}^{7,12,13,18}$. In particular, the elastic properties are not only dependent on the mineral phase, but also on its chemical composition. Therefore, to extend the applicability of elastic geobarometry to various inclusion types, it is crucial to determine the EoS for a larger number of minerals and compositions. Moreover, elastic geobarometry could lead to incorrect estimates of entrapment conditions if the following factors are not adequately considered: (i) the occurrence of brittle or plastic deformation in the host diamond; (ii) the shape of the inclusion and its distance from other inclusions and from the external surfaces of the diamond ${ }^{16}$; (iii) the elastic anisotropy of the host and of the inclusion ${ }^{15,17,19-21}$; (iv) the presence of a fluid rim around the inclusions observed in several diamonds $\mathrm{s}^{17,22,23}$. In this light, $\mathrm{mchr}$ inclusions in lithospheric diamonds could be among the best candidates for elastic geobarometry, because (a) plastic deformation is generally minor in lithospheric diamonds compared with higher-T and highly strained sub-lithospheric diamonds; (b) the mchr crystal shape is often equant to almost rounded, thus the "geometrical effect" is small ${ }^{16}$, and (b) both mchr and diamond have a cubic symmetry and their elastic behavior can be approximated as isotropic. A possible problem is the presence of a fluid rim, which is quite common at the interface between mchr and diamond ${ }^{22}$. The elastic properties of such fluid are not known, but its estimated thickness is so limited (even less than $1 \mu \mathrm{m}$ ) that its effect can reasonably be neglected, at least in the absence of cracks departing from the host-inclusion interface.

At present, the main obstacle to the application of elastic geobarometry to mchr-bearing diamonds is the knowledge of the EoS of mchr. The variations in published values for bulk modulus and its first pressure derivative for mchr with different compositions ${ }^{24-26}$ indicate a degree of uncertainty that is too large for reliable geobarometry. To circumvent this problem, we have determined experimentally an EoS for a single mchr crystal, sample Ac139, which had been extracted from a Siberian diamond. We used state-of-art high-pressure techniques (see Methods) in order to get accurate and precise unit-cell volumes as a function of $P$. The resulting EoS was applied to a second mchr inclusion, sample MgCr2, Fig. 1, in another Siberian diamond from the Udachnaya kimberlite with the aim of determining the depth of diamond formation.

The chemical compositions of $\mathrm{Ac} 139$ and $\mathrm{MgCr} 2$ are the following:

Ac139: $\mathrm{Mg}_{0.64} \mathrm{Fe}_{0.40} \mathrm{Cr}_{1.73} \mathrm{Al}_{0.22} \mathrm{Ti}_{0.01} \mathrm{Mn}_{0.01} \mathrm{O}_{4}$

MgCr2: $\mathrm{Mg}_{0.64} \mathrm{Fe}_{0.42} \mathrm{Cr}_{1.66} \mathrm{Al}_{0.26} \mathrm{Ti}_{0.02} \mathrm{~V}_{0.04} \mathrm{O}_{4}$

Not only these two samples show very similar compositions (see chemical compositions in oxide wt\%, Supplementary Table 1), but they also have compositions typical for $\mathrm{mchr}$ in diamonds ${ }^{1}$. 

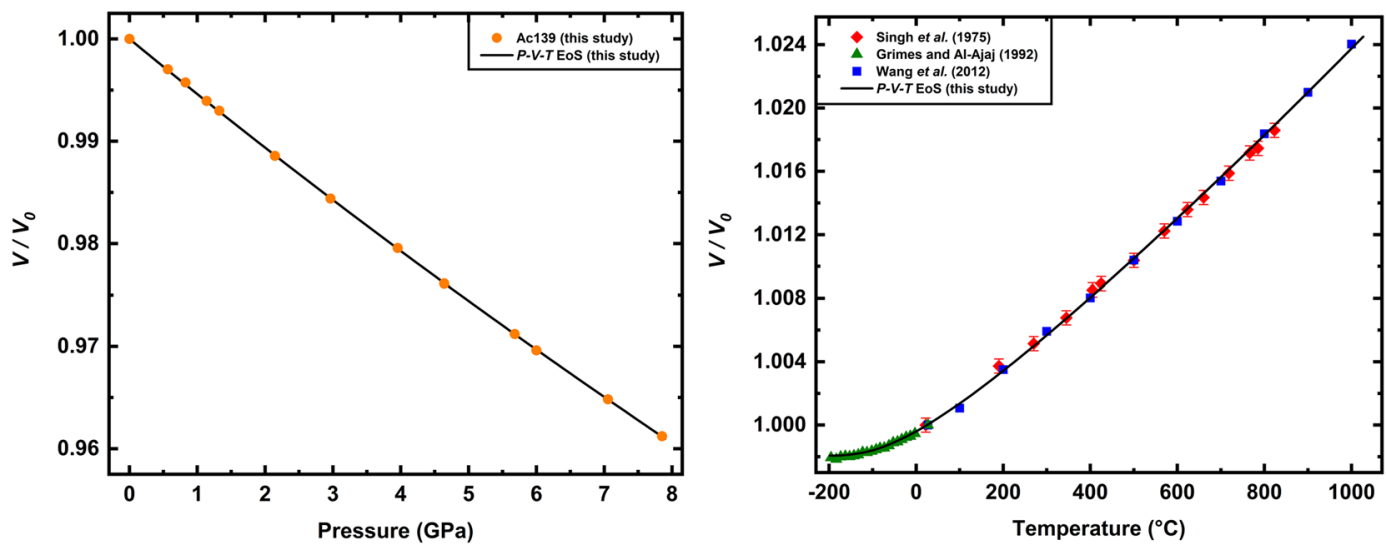

Figure 2. (a) Fractional unit-cell volume as a function of pressure measured in this work for Ac139 spinel. Uncertainties are smaller than symbols. (b) Fractional unit-cell volume as a function of temperature from literature ${ }^{29-31}$. The black line represents the fitting to the $P-V$ and $T-V$ data obtained from a BM2 EoS combined with the thermal- $P$ model ${ }^{28}$. See text and Supplementary Table 3 for further details.

The results from the elastic geobarometry applied to diamond-mchr host-inclusion system in this work provide the first direct determination of provenance depth for a mchr-bearing diamond and new constraints on the thermal state and composition of the deep Siberian cratonic lithosphere at the time of diamond formation.

Pressure-Volume-Temperature Equation of State of Reference mchr. The best fit to the $P-V$ data (Fig. 2a and Supplementary Table 2) for Ac139 is obtained for a second-order Birch-Murnaghan (BM2) EoS ${ }^{27}$, which gives the following parameters at room conditions: unit-cell volume $V_{0}=576.19(3) \AA^{3}$, Reuss isothermal bulk modulus $K_{\mathrm{RT} 0}=182.8(6) \mathrm{GPa}$ (first pressure derivative $K_{\mathrm{RT} 0}{ }^{\prime}$ fixed to 4 ).

The full thermoelastic behavior of a mineral can be expressed through a $P-V-T$ EoS that incorporates the concept of thermal pressure ${ }^{28}$. We therefore estimated the $P-V-T$ EoS of Ac139 by combining the BM2 EoS at room conditions with the $T-V$ data available in the literature for similar compositions. To constrain the high- $T$ thermal behavior of our Ac139, we selected data ${ }^{29}$ obtained on a natural mchr spinel with composition $\mathrm{Mg}_{0.58} \mathrm{Fe}_{0.42} \mathrm{Cr}_{1.52} \mathrm{Al}_{0.48} \mathrm{O}_{4}$ to $823^{\circ} \mathrm{C}$, and those obtained ${ }^{30}$ on a synthetic magnesiochromite crystal $\left(\mathrm{MgCr}_{2} \mathrm{O}_{4}\right)$ to $1000^{\circ} \mathrm{C}$. Figure $2 \mathrm{~b}$ shows that the normalized unit-cell volumes as a function of $T$ reported in these two studies are in very good agreement, suggesting that relatively large substitutions of $\mathrm{Mg}$ for $\mathrm{Fe}$ and of $\mathrm{Cr}$ for $\mathrm{Al}$ have negligible effects on the thermal behavior. Moreover, the literature data ${ }^{30}$ clearly show no cation order-disorder process, implying no order-disorder also for the mixed composition ${ }^{29}$. Since the chemical composition of sample Ac139 lies between the two chemical compositions investigated in the literature ${ }^{29,30}$, these two datasets can be considered representative also of its high- $T$ behavior. To further constrain the thermal behavior, we also used the low- $T$ data ${ }^{31}$ obtained on a synthetic polycrystalline $\mathrm{MgAl}_{2} \mathrm{O}_{4}$ spinel from $-196^{\circ} \mathrm{C}$ to room- $T$. The incorporation of the low- $T$ data $^{31}$, even referring to a chemical composition that is different from Ac139, does not affect the final fitting, but provides a further constraint (i.e. lower uncertainties) for the thermal EoS parameters. On a cubic mineral, like mchr, in which the thermal expansion and the axial moduli are equal in all directions, a thermal pressure model based on the quasi-harmonic approximation ${ }^{28}$ can be applied. Therefore, in order to determine the $P-V-T$ EoS for mchr, we fitted $P-V$ data for Ac139 and the selected $T-V$ data from the literature by combining our BM2 EoS with the thermal pressure model ${ }^{28}$. The final $P-V-T$ EoS parameters are reported in Supplementary Table 3. Considering that the bulk modulus is practically identical for both $\mathrm{MgCr}_{2} \mathrm{O}_{4}$ and $\mathrm{FeCr}_{2} \mathrm{O}_{4}{ }^{25}$ and that thermal expansion does not show significant variations for mixed compositions between magnesiochromite and chromite ${ }^{29,30}$, we are confident that our $P-V$ - $T$ EoS parameters can be applied to a wide range of mchr compositions, including the sample here investigated $\mathrm{MgCr} 2$.

Relatively to the effect of inversion of the spinel component on the inclusion volume at elevated temperature, it is negligible. In fact, for $\mathrm{MgAl}_{2} \mathrm{O}_{4}$ spinel from inversion $(\mathrm{x})=0$, corresponding to an ideally ordered phase, to $\mathrm{x}=0.29$, corresponding to disorder at $1100^{\circ} \mathrm{C}$, volume change is only $0.3 \%$, that is from 529.475 to $528.082 \mathrm{~A}^{3}$ $\left(\right.$ ref. $\left.^{32}\right)$.

The effect of pressure is also negligible, as up to $7.5 \mathrm{GPa}$ pressure has little or no influence on the degree of order in the $\mathrm{MgAl}_{2} \mathrm{O}_{4}$ spinel $^{33}$.

Moreover, the influence of inversion on the elastic properties of $\mathrm{MgAl}_{2} \mathrm{O}_{4}$ spinel is also very limited. In fact, from $\mathrm{x}=0$ to $\mathrm{x}=0.30$, the decrease of bulk modulus $K_{\mathrm{RT}}$ is about $1 \%$, as shown by comparing results of density functional theory and Brillouin scattering technique ${ }^{34}$. Please note that all the considerations above refer to a pure $\mathrm{MgAl}_{2} \mathrm{O}_{4}$ spinel, whereas the $\mathrm{MgAl}_{2} \mathrm{O}_{4}$ component of our magnesiochromite inclusions is at maximum $13 \%$.

Diamond Residence Temperature and Depth of Formation of the Diamond-mchr pair. The Fourier transform infrared (FTIR) measurements on the MgCr2 diamond host indicate an average $\mathrm{N}$ content $\left(\mathrm{N}_{\text {tot }}\right)$ of $267 \mathrm{ppm}$ and an aggregation of B defects percentage (\%IaB) of 32\% (Supplementary Table 4). In Fig. 3 we show one of the FTIR spectra we have collected on MgCr2 diamond host (in Supplementary Data 1 to 6 all FTIR spectra were available). These values are typical for Udachnaya diamonds ${ }^{35}$ and allow to classify the diamond as 


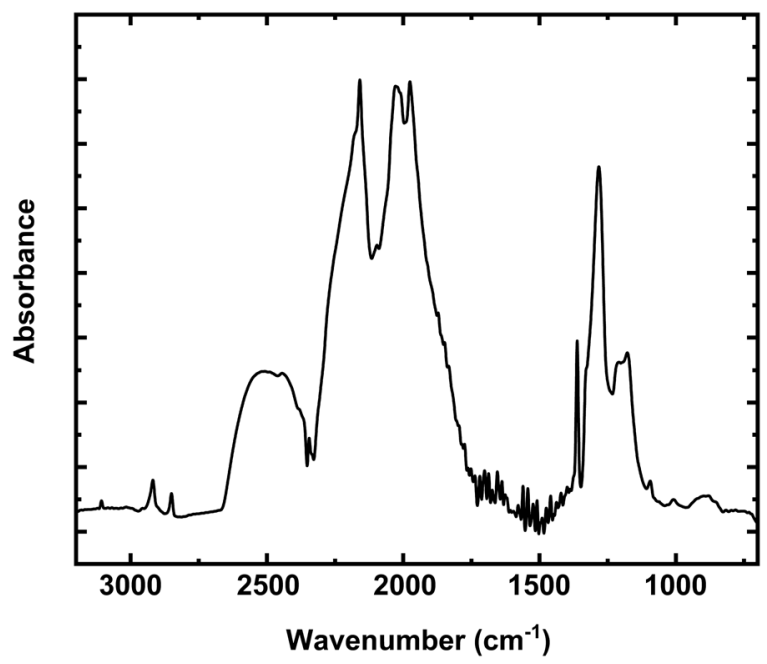

Figure 3. Representative FTIR spectrum of the diamond host (referred to Ud_4 measurement in Supplementary Table 4 and Supplementary Data 4 ).

Type-IaAB. Based on the procedure reported in the Methods and taking into account the age of the host kimberlite (ca. $360 \mathrm{Ma}^{36}$ ), our calculations indicate a mantle residence temperature, $T_{\text {res }}$, of $1125(32){ }^{\circ} \mathrm{C}$ for a diamond age of $3.5 \mathrm{Ga}$ and of $1140(33)^{\circ} \mathrm{C}$ for a diamond age of $2 \mathrm{Ga}$ (Supplementary Table 4). These two ages cover the range of reported ages for Udachnaya diamonds ${ }^{37-39}$. The retrieved $T_{\text {res }}$ values differ by less than their respective uncertainties and lie within the typical range of $T_{\text {res }}$ for peridotitic diamonds from Udachnaya (ca. $1125-1175^{\circ} \mathrm{C}$, ref. ${ }^{37}$ ). Since a short residence at higher $T$ during the early history of the diamond would have not produced significant effects on the final $\mathrm{N}$-aggregation state, the estimated $T_{r e s}$ of $1125-1140^{\circ} \mathrm{C}$ can be considered as a minimum $T$ estimate for diamond formation.

The SC-XRD measurements performed on inclusion MgCr2 before and after its release from the diamond provided unit-cell volumes $\left(V_{0}\right)$ of 573.3(2) and 576.63(2) $\AA^{3}$, respectively. We used our $P-V$ EoS (Supplementary Table 2) to convert the residual volume strain recorded by the inclusion still trapped in the host diamond into the hydrostatic component of the residual stress, i.e. the residual pressure $\left(P_{\text {inc }}\right)$, and obtained a value of 1.073(72) $\mathrm{GPa}$ at room conditions. The esd on $P_{i n c}$ was calculated by propagation of uncertainties on the EoS parameters (see Supplementary Table 3 ) and on $V_{0}$ measurements. Using this $P_{i n c}$, the $P-V-T$ EoS determined for the compositionally similar mchr Ac139, and the $P-V-T$ EoS for diamond ${ }^{7}$, we can now calculate the entrapment conditions for the $\mathrm{MgCr} 2$ inclusion (shape of the inclusion and its distance from the diamond surface did not require further correction $\mathrm{s}^{16}$ ). Since both the host and the inclusion have cubic symmetry, we can apply the geobarometric model developed for isotropic systems and calculate the entrapment isomeke for the specific $P_{i n c}$ using the EosFit-Pinc software $^{10}$. The entrapment isomeke is the line that defines all the possible entrapment conditions for a given $P_{i n c}$ $\left(\right.$ refs $\left.^{6,8}\right)$. A specific entrapment pressure $\left(P_{\text {trap }}\right)$ can be obtained if the $T_{\text {trap }}$ is independently constrained. Since the isomeke has a small $\partial P / \partial T$, the $T$-dependency of the elastic geobarometer is low. Assuming for the $\mathrm{MgCr} 2$ inclusion a minimum $T_{\text {trap }}$ equal to the estimated $T_{\text {res }}$ of $1125-1140^{\circ} \mathrm{C}$, we obtain a minimum $P_{\text {trap }}$ of $6.5(2) \mathrm{GPa}$ (the uncertainty derives from the error propagation of all parameters used to calculate it), corresponding to a minimum depth of about 205(6) km (Fig. 4; the data used to plot the entrapment isomeke in figure are reported in Supplementary Table 5; the input files to run EosFit-Pinc software for our diamond - MgCr2 pair are available in Supplementary Data 7 and 8).

The P-T Conditions of the Diamond-mchr System: Implications for the Mantle Under Udachnaya. Thermobarometric data obtained for mantle xenoliths from the Udachnaya kimberlite show relatively large scatter compared to many other cratonic mantle sections, making it difficult to outline a unique geotherm for this locality ${ }^{40}$ (Fig. 4). Existing data suggest that the mantle under Udachnaya experienced very cold conditions during at least part of its history, as testified by several peridotites and peridotitic garnets falling close to a ca. $35 \mathrm{~mW} / \mathrm{m}^{2}$ conductive geotherm $\mathrm{m}^{40,41}$. The lithosphere under Udachnaya extended to ca. $230 \mathrm{~km}$ depth at the time of kimberlite eruption, but the depth extension of the cold geotherm is poorly constrained due to scatter of $P-T$ data. In fact, the deepest portion of the lithosphere records significant thermal perturbation, with the majority of high- $P$ xenoliths ( $>5 \mathrm{GPa}$ ) being shifted to ca. $200-300^{\circ} \mathrm{C}$ higher $T$ (ref. ${ }^{40}$ ) (Fig. 4 ).

The estimated $P_{\text {trap }}-T_{\text {res }}$ conditions for diamond $-\mathrm{MgCr} 2$ pair $\left(6.5 \mathrm{GPa}\right.$ at ca. $1130^{\circ} \mathrm{C}$; see the $P-T$ data relative to the isomeke in Fig. 4 provided between 700 and $1400^{\circ} \mathrm{C}$ in Supplementary Data 9) fall right on the $35 \mathrm{~mW} / \mathrm{m}^{2}$ geotherm (Fig. 4). This indicates that cold conditions have persisted for a long geological time in the Udachnaya lithosphere to at least $200 \mathrm{~km}$ depth. Heating processes shortly before or during kimberlite eruption might lead to overestimation of the real $T_{\text {res }}$ in the mantle and, consequently, of $P_{\text {trap }}$. However, this effect cannot be significant, otherwise $P-T$ estimates along the entrapment isomeke would become incompatible with even the coldest cratonic geotherm (Fig. 4). We cannot exclude that our diamond has formed during a short thermal pulse at conditions somewhat hotter than the $35 \mathrm{~mW} / \mathrm{m}^{2}$ geotherm, as this would not be recorded in its $\mathrm{N}$-aggregation state $^{1}$. In this case, however, the real $P_{\text {trap }}$ would be slightly higher (e.g. ca. $7 \mathrm{GPa}$ for a $T_{\text {trap }}$ of $1300^{\circ} \mathrm{C}$ ) and the 


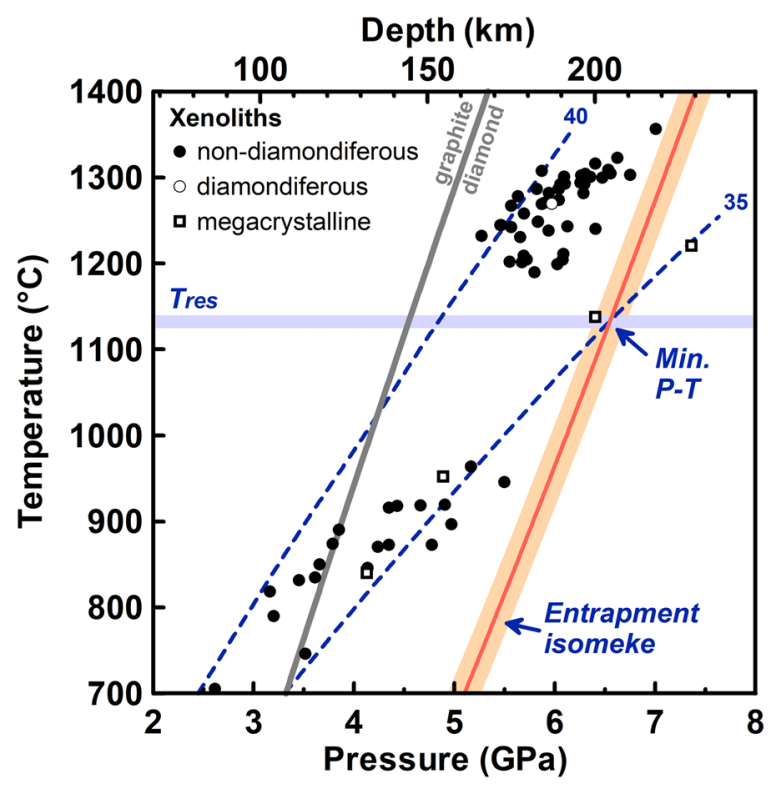

Figure 4. Pressure-temperature diagram showing the calculated entrapment isomeke for $\mathrm{MgCr} 2$ diamondinclusion pair. $T_{\text {res }}$ is the residence $T$ based on diamond $\mathrm{N}$-aggregation state. $P-T$ estimates for Udachnaya peridotitic xenoliths (lherzolites) are mostly based on the combination of the orthopyroxene-garnet barometer $^{61}$ with the two-pyroxene thermometer ${ }^{62}$. For the three highest- $P$ megacrystalline peridotites (clinopyroxene-free) the orthopyroxene-garnet thermometer ${ }^{63}$ was used. Note that this thermometer is less reliable as it is sensitive to redox conditions ${ }^{64}$. Xenolith data are from the compilation of well-equilibrated lherzolites $^{63}$, with additional data on megacrystalline peridotites ${ }^{40,65}$. Conductive geotherms for 35 and $40 \mathrm{~mW} /$ $\mathrm{m}^{2}$ are after ref. ${ }^{66}$; the diamond-graphite boundary is after ref. ${ }^{67}$.

depth extension of the long-lived cold geotherm would only be greater (i.e., to ca. $1130^{\circ} \mathrm{C}$ and $7 \mathrm{GPa}$, or $220 \mathrm{~km}$ ). Much higher $P_{\text {trap }}$, however, would imply long-term residence at conditions, again, too cold for a cratonic lithosphere (Fig. 4). For the same reasons, significant $P_{\text {trap }}$ underestimation due to plastic deformation and $P_{\text {inc }}$ relaxation can be excluded. Disregarding the inevitable small discrepancies between $P-T$ estimates obtained with different thermobarometric methods, our results provide independent confirmation of literature hypothesis ${ }^{41}$, based on scanty xenolith (megacrystalline peridotites) and garnet xenocryst data, that a cold $35 \mathrm{~mW} / \mathrm{m}^{2}$ geotherm originally extended to ca. $1200^{\circ} \mathrm{C}$.

Abundant experimental data and thermodynamic modeling ${ }^{2,42-46}$ showed that the stability of mchr in peridotite is strongly dependent on the peridotite 'fertility' and that in the garnet-spinel stability field Cr\# ${ }_{\text {spinel }}$ increases rapidly with increasing $P$ and slightly with decreasing $T$. At given $P-T, \mathrm{Cr} \#_{\text {spinel }}$ depends on the spinel modal abundance and is thus lower in more spinel-rich, more depleted peridotites ${ }^{2}$. Thermodynamic modeling in natural peridotitic systems $\mathrm{s}^{2}$ predicts that, along a $35 \mathrm{~mW} / \mathrm{m}^{2}$ geotherm in very depleted harzburgite with bulk $\mathrm{Cr} \#=0.32$, spinel is only stable to $5.5 \mathrm{GPa}$ and $1000^{\circ} \mathrm{C}$, where it reaches a Cr\# ${ }_{\text {spinel }}$ of ca. 0.9 . These conditions are not compatible with our $P-T$ estimates (Fig. 4). Along hotter geotherms or in less depleted peridotites, the stability of spinel would be restricted to even lower $P$. This suggests that our mchr belonged to a more depleted, possibly dunitic and spinel-rich assemblage. The persistence of a $\mathrm{Cr} \# \sim 0.9$ (namely, 0.86) in our mchr at $6.5 \mathrm{GPa}$ further supports this hypothesis.

Compared with classical xenolith geothermobarometry, diamond elastic geothermobarometry has a considerable potential to yield ancient lithospheric thermal states, because diamonds can be very old, and their inclusions remain exceptionally preserved from chemical exchanges with surrounding minerals, fluids and melts even under dramatically changing physico-chemical conditions. With our unprecedented application of elastic geothermobarometry to a mchr inclusion in a gem-quality octahedral diamond from the Udachnaya kimberlite, we provided evidence that cold conditions corresponding to a ca. $35 \mathrm{~mW} / \mathrm{m}^{2}$ geotherm persisted for billions of years to a depth of at least $200 \mathrm{~km}$ in the Siberian craton lithosphere, and that at this depth the lithosphere was, at least locally, ultra-depleted.

\section{Methods}

Samples. We have studied two mchr samples: the first sample was a released crystal used to determine the EoS of mchr, while the second sample was still included within a diamond and was used to determine the depth of formation of the diamond-mchr host-inclusion pair using the thermoelastic properties determined on the first one. The first mchr, labeled Ac139, is a mchr single crystal with a size of $42 \times 25 \times 15 \mu^{3}$ and high crystal quality, i.e. sharp diffraction profiles and absence of twinning and inclusions. It was extracted from a lithospheric diamond from the Aikhal kimberlite (Siberia, Russia) by crushing the diamond and then studied by in-situ high-pressure single-crystal $\mathrm{X}$-ray diffraction. The second $\mathrm{mchr}$, labeled $\mathrm{MgCr} 2$, was included in a gemstone octahedral diamond (longest dimension $=2.15 \mathrm{~mm}$ ) from the Udachnaya kimberlite, Siberia, Russia (Fig. 1), and belongs to the same set of diamonds previously studied ${ }^{22,47}$. The $\mathrm{MgCr} 2$ inclusion was alone within its host and located in intermediate position between 
the gravimeter center and external surface of the diamond. Its morphology is nearly equant cube-octahedral, with an average crystal radius of $0.34 \mathrm{~mm}$, and no optically visible fractures were observed. The mchr inclusion was extracted from its host by crushing the diamond only after a first set of in-situ X-ray analyses.

Electron microprobe analyses. Chemical analyses were carried out on sample Ac139 using a CAMECA SX50 electron microprobe (WDS mode, $20 \mathrm{kV}, 20 \mathrm{nA}, 2 \mu \mathrm{m}$ beam diameter) at CNR-IGG of Padova. Standards

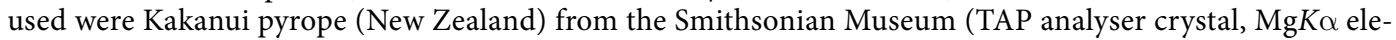
ment emission line); Amelia albite (Virginia) (TAP, $\mathrm{NaK \alpha}$ ); diopside (TAP, $\mathrm{SiK \alpha}$ ); $\mathrm{Al}_{2} \mathrm{O}_{3}$ (TAP, $\mathrm{AlK \alpha}$ ); $\mathrm{MnTiO}_{3}$

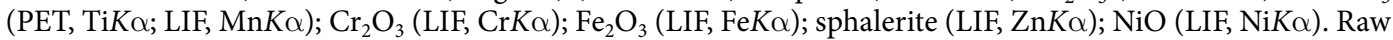
data were reduced with the PAP-type correction software provided by CAMECA. The resulting oxides wt $\%$ are reported in Supplementary Table 1. Chemical analyses on sample MgCr2 were carried out by standardless EDS analysis on a FEG scanning-electron microscope, using an Oxford Instruments SDD detector and the AZtec TruQ software installed at the Oxford Instruments in Wiessbaden (Germany).

Fourier transform Infrared spectroscopy. Fourier Transform Infrared (FTIR) were acquired using a Thermo Scientific Nicolet Centaurus FT-IR Microscope (located at the Department of Industrial Engineering, University of Padova) operated via OMNIC software. The spectra were collected in the $4000-650 \mathrm{~cm}^{-1}$ wavelength range, with 64 scans of sample exposure and $0.5 \mathrm{~cm}^{-1}$ of spectral resolution. The background spectra were run for $120 \mathrm{~s}$ before the analyses and the sample spectra were subtracted by them. The measurements were performed on a diamond plate collected from the diamond crushed material after the MgCr 2 crystal release. The plate was mounted in wax to allow the analyses in transmission mode. We acquired different FTIR spectra over six different locations on the plate with an FTIR spot of about $100 \mu \mathrm{m}$, covering most of its area. The absorbance spectra were processed using DiaMap ${ }^{48,49}$ to obtain the $\mathrm{N}$ content and aggregation state ${ }^{50}$. This program fits the individual $\mathrm{N}$ absorption band and deconvolutes the spectrum in the 1001 to $1350 \mathrm{~cm}^{-1}$ range. Then, the concentrations of $\mathrm{N}$ impurities aggregated in pairs (A defects) and of $\mathrm{N}$ impurities aggregated in clusters plus vacancy (B defects) were calculated using literature absorption coefficients ${ }^{51,52}$. Errors in calculation of $\mathrm{N}$ content and aggregation state are considered of $\pm 10 \%{ }^{48}$ and depend on the quality of the FTIR spectra. The original FTIR spectra collected in these analyses are reported in the supplementary data (1 to 6), while the data on $\mathrm{N}$ content and aggregation state are reported in Supplementary Table 4. A representative FTIR spectrum for the diamond host of the sample $\mathrm{MgCr} 2$ (data from such spectrum are relative to Ud_4 in Supplementary Table 4) is shown in Fig. 2.

We used the constants from the literature ${ }^{53,54}$ (i.e. $E / R=81160 \mathrm{~K} ; \ln (A)=12.59$; where: $E=$ activation energy; $R=$ gas constant; $A=$ Arrhenius constant) to calculate the residence temperature, $T_{r e s}$, as a function of time for the $\mathrm{MgCr} 2$ diamond. The age of our diamond is unknown, but previous geochronological work on Udachnaya diamonds suggested two major peaks of diamond formation, one at 3.1-3.5 Ga (Re-Os dating on sulphide inclusions $^{35,36}$ ) and one at ca. $2 \mathrm{Ga}\left(\mathrm{Sm}-\mathrm{Nd}\right.$ dating on garnet inclusions $\left.{ }^{37}\right)$.

The calculations indicate a mantle residence temperature, $T_{r e s}$, of $1125(32){ }^{\circ} \mathrm{C}$ for the oldest age $(3.5 \mathrm{Ga})$ and of $1140(33){ }^{\circ} \mathrm{C}$ for the youngest age $(2 \mathrm{Ga})$. Uncertainties reported in parentheses (estimated standard deviations, esd) were calculated from the propagation of the uncertainties on the FTIR measurement and on constants taken from literature ${ }^{53,54}$.

X-ray diffraction measurements. In-situ high-pressure single-crystal X-ray diffraction (SC-XRD) experiments were performed on mchr Ac139, in order to determine its thermoelastic properties and Pressure - Volume Equation of State. The crystal was loaded in an ETH-type diamond-anvil cell (DAC) equipped with Be-backing plates $^{55}$. We used a steel gasket pre-indented to a thickness of about $90 \mu \mathrm{m}$ with a spark-eroded hole of $250 \mu \mathrm{m}$ in diameter and a mixture of methanol:ethanol with ratio $4: 1$ to ensure hydrostatic pressures up to the maximum $P$ reached in this work $(7.852 \mathrm{GPa}$ ) (it is well established that for such pressure values the mixture used behaves hydrostatically ${ }^{56}$ ). The diameter of the diamond culet was $600 \mu \mathrm{m}$. The sample was loaded together with a single crystal of quartz used as an internal pressure standard ${ }^{57}$. The unit-cell edge was measured on a four-circle STOE STADI IV diffractometer equipped with a point detector and controlled by the SINGLE software ${ }^{58}$ and installed at the Department of Geosciences, University of Padova. The SINGLE software is based on the 8-position centering method ${ }^{59}$ and vector least-squares refinement of the unit-cell parameters ${ }^{60}$. The data were acquired using $\mathrm{MoK \alpha}$ radiation at $50 \mathrm{kV}$ and $40 \mathrm{~mA}$. Unit-cell parameters were determined from the centering of an average of 19 reflections for each high-pressure measurement, in the $2 \theta$ range between $8^{\circ}$ and $34^{\circ}$. The unit-cell edges and unit-cell volumes at different pressures are reported in Supplementary Table 2.

The determination of the residual pressure $\left(P_{\text {inc }}\right)$ on inclusion $\mathrm{MgCr} 2$ was obtained by comparing the unit-cell parameters measured on the crystal when still trapped in its host and, then, in air after extraction from the diamond. The SC-XRD measurements were performed by using a Rigaku-Oxford Diffraction Supernova diffractometer equipped with a micro-source $\mathrm{MoK} \alpha$ radiation, working at $50 \mathrm{kV}$ and $0.8 \mathrm{~mA}$ and with a sample-to-detector distance of $68 \mathrm{~mm}$, and a Pilatus $200 \mathrm{~K}$ Dectris detector. The diffractometer was installed at the Department of Geosciences, University of Padova. The unit-cell edges before and after the release from the diamond host were measured by collecting data up to $2 \theta=80^{\circ}$, using a thin slicing in $\omega$ of $0.1^{\circ}$ (see values at the section Diamond residence temperature and depth of formation of the diamond-mchr pair).

\section{References}

1. Stachel, T. \& Harris, J. W. The origin of cratonic diamonds - Constraints from mineral inclusions. Ore Geol. Rev. 34, 5-32 (2008).

2. Ziberna, L., Klemme, S. \& Nimis, P. Garnet and spinel in fertile and depleted mantle: insights from thermodynamic modelling. Contrib. Mineral. Petr. 166, 411-421 (2013).

3. Rosenfeld, J. L. \& Chase, A. B. Pressure and temperature of crystallization from elastic effects around solid inclusions in minerals? Am. J. Sci. 259, 519-541 (1961). 
4. Adams, H. G., Cohen, L. H. \& Rosenfeld, J. L. Solid inclusion piezothermometry I: comparison dilatometry. Am. Mineral. 60, 574-583 (1975).

5. Angel, R. J., Gonzalez-Platas, J. \& Alvaro, M. EosFit7c and a Fortran module (library) for equation of state calculations. Z. Krist. 229, 405-419 (2014a)

6. Angel, R. J., Mazzucchelli, M. L., Alvaro, M., Nimis, P. \& Nestola, F. Geobarometry from host-inclusion systems: the role of elastic relaxation. Am. Mineral. 99, 2146-2149 (2014b).

7. Angel, R. J., Alvaro, M., Nestola, F. \& Mazzucchelli, M. L. Diamond thermoelastic properties and implications for determining the pressure of formation of diamond-inclusion systems. Russ. Geol. Geophys. 56, 211-220 (2015a).

8. Angel, R. J., Nimis, P., Mazzucchelli, M. L., Alvaro, M. \& Nestola, F. How large are departures from lithostatic pressure? Constraints from host-inclusion elasticity. J. Metamorph. Geol. 33, 801-803 (2015b).

9. Angel, R. J., Alvaro, M., Miletich, R. \& Nestola, F. A simple and generalised P-T-V EoS for continuous phase transitions, implemented in EosFit and applied to quartz. Contrib. Mineral. Petrol. 172, 29 (2017a).

10. Angel, R. J., Mazzucchelli, M. L., Alvaro, M. \& Nestola, F. EosFit-Pinc: A simple GUI for host-inclusion elastic thermobarometry. Am. Mineral. 102, 1957-1960 (2017b).

11. Angel, R. J. et al. Stress, strain and Raman shifts. Z. Krist. 234, 129-140 (2019).

12. Milani, S. et al. Diamond-garnet geobarometry: The role of garnet compressibility and expansivity. Lithos 227, 140-147 (2015).

13. Milani, S. et al. Thermoelastic behaviour of grossular garnets at high pressures and temperatures. Am. Mineral. 102, 851-859 (2017).

14. Anzolini, C. et al. Depth of formation of $\mathrm{CaSiO}_{3}$-walstromite included in super-deep diamonds. Lithos 265, 138-147 (2016).

15. Anzolini, C. et al. Depth of formation of super-deep diamonds: Raman barometry of $\mathrm{CaSiO}_{3}$-walstromite inclusions. Am. Mineral. 103, 69-74 (2018).

16. Mazzucchelli, M. L. et al. Elastic geothermobarometry: corrections for the geometry of the host-inclusion system. Geology 46, 231-234 (2018).

17. Nestola, F. et al. Toward a robust elastic geobarometry of kyanite inclusions in eclogitic diamonds. J. Geophys. Res. 123, 6411-6423 (2018).

18. Angel, R. J., Alvaro, M. \& Nestola, F. 40 years of mineral elasticity: a critical review and a new parameterisation of equations of state for mantle olivines and diamond inclusions. Phys. Chem. Miner. 45, 95-113 (2017c).

19. Campomenosi, N. et al. How geometry and anisotropy affect residual strain in host-inclusion systems: Coupling experimental and numerical approaches. Am. Mineral. 103, 2032-2035 (2018).

20. Murri, M. et al. Raman elastic geobarometry for anisotropic mineral inclusions. Am. Mineral. 103, 1869-1872 (2018).

21. Murri, M., Alvaro, M., Angel, R. J., Prencipe, M. \& Mihailova, B. D. The effects of non-hydrostatic stress on the structure and properties of alpha-quartz. Phys. Chem. Miner. https://doi.org/10.1007/s00269-018-01018-6 (2019).

22. Nimis, P. et al. First evidence of hydrous silicic fluid films around solid inclusions in gem-quality diamonds. Lithos 260, 384-389 (2016).

23. Smith, E. M. et al. Large gem diamonds from metallic liquid in Earth’s deep mantle. Science 354, 1403-1405 (2016).

24. Yong, W., Botis, S., Shieh, S. R., Shi, W. \& Withers, A. C. Pressure-induced phase transition study of magnesiochromite $\left(\mathrm{MgCr}_{2} \mathrm{O}_{4}\right)$ by Raman spectroscopy and X-ray diffraction. Phys. Earth Planet. In. 196-197, 75-82 (2012).

25. Nestola, F. et al. Pressure-volume equation of state for chromite and magnesiochromite: A single-crystal X-ray diffraction investigation. Am. Mineral. 99, 1248-1253 (2014).

26. Zhang, Y. Y., Liu, X., Xiong, Z. \& Zhang, Z. Compressional behavior of $\mathrm{MgCr}_{2} \mathrm{O}_{4}$ spinel from first-principles simulation. Sci. China Earth Sci. 59, 989-996 (2016).

27. Birch, F. Finite elastic strain of cubic crystals. Phys. Rev. 71, 809 (1947).

28. Holland, T. J. B. \& Powell, R. An improved and extended internally consistent thermodynamic dataset for phases of petrological interest, involving a new equation of state for solids. J. Metamorph. Geol. 29, 333-383 (2011).

29. Singh, H. P., Simmons, G. \& McFarlin, P. F. Thermal expansion of natural spinel, ferroan gahnite, magnesiochromite and synthetic spinel. Acta Crystall. A 31, 820-822 (1975).

30. Wang, S., Liu, X., Fei, Y., He, Q. \& Wang, H. In situ high-temperature powder X-ray diffraction study on the spinel solid solutions (Mg1- xMnx) $\mathrm{Cr}_{2} \mathrm{O}_{4}$. Phys. Chem. Miner. 39, 189-198 (2012).

31. Grimes, N. W. \& Al-Ajaj, E. A. Low-temperature thermal expansion of spinel. J. Phys. 4, 6375 (1992).

32. Andreozzi, G. B., Princivalle, F., Skogby, H. \& Della Giusta, A. Cation ordering and structural variations with temperature in $\mathrm{MgAl}_{2} \mathrm{O}_{4}$ spinel: An X-ray single-crystal study. Am. Mineral. 85, 1164-1171 (2000).

33. Nestola, F. et al. Comparative compressibility and structural behavior of spinel $\mathrm{MgAl} 2 \mathrm{O} 4$ at high pressures: The independency on the degree of cation order. Am. Mineral. 92, 1838-1843 (2007).

34. Nunez-Valdez, M. et al. Reexploring the cation ordering and magnetic cation substitution effects on the elastic anisotropy of aluminum spinels. J. Appl. Phys. 124, 175901 (2018).

35. Palot, M. et al. Multiple Growth Episodes or Prolonged Formation of Diamonds? Inferences from Infrared Absorption Data. J. Geol. Soc. India. 1, 281-296 (2013).

36. Kinny, P. D., Griffin, B. J., Heaman, L. M., Brakhfogel, F. F. \& Spetsius, Z. V. SHRIMP U-Pb ages of perovskite from Yakutian kimberlites. Russian Geol. Geophys. 38, 97-105 (1997).

37. Richardson, S. H. \& Harris, J. W. Antiquity of peridotitic diamonds from the Siberian craton. Earth Planet. Sci. Lett. 151, 271 (1997).

38. Pearson, D. G., Shirey, S. B., Bulanova, G. P., Carlson, R. W. \& Milledge, H. J. Re-Os isotope measurements of single sulfide inclusions in a Siberian diamond and its nitrogen aggregation systematics. Geochim. Cosmochim. Acta 63, 703 (1999).

39. Pearson, D. G. et al. (eds) The P. H. Nixon Volume-Proceedings of the Seventh International Kimberlite Conference, Cape Town, Red Roof Design, Cape Town, pp 637-643 (1999).

40. Doucet, L. S., Ionov, D. A. \& Golovin, A. V. The origin of coarse garnet peridotites in cratonic lithosphere: new data on xenoliths from the Udachnaya kimberlite, central Siberia. Contrib. Mineral. Petr. 165, 1225-1242 (2013).

41. Griffin, W. L. et al. Thermal state and composition of the lithospheric mantle beneath the Daldyn kimberlite field, Yakutia. Tectonophysics 262, 19-33 (1996).

42. O'Neill, H. S. C. The transition between spinel lherzolite and garnet lherzolite, and its use as a geobarometer. Contrib. Mineral. Petrol. 77, 185-194 (1981).

43. Nickel, K. G. Garnet-pyroxene equilibria in the system SMACCR $\left(\mathrm{SiO}_{2}-\mathrm{MgO}-\mathrm{Al}_{2} \mathrm{O}_{3}-\mathrm{CaO}-\mathrm{Cr}_{2} \mathrm{O}_{3}\right)$ : the Cr-geobarometer. In Ross, J., Jaques, A. L., Ferguson, J., Green, D. H., O’Reilly, S. Y., Danchin, R. V., Janse, A. J. A. (eds) Kimberlites and related rocks, vol. 2, their mantle/crust setting, diamonds and diamond exploration. Geological Society of Australia Special Publication 14. Blackwell Scientific, Victoria, pp 901-912 (1989)

44. Webb, S. A. C. \& Wood, B. J. Spinel-pyroxene-garnet relationships and their dependence on $\mathrm{Cr} / \mathrm{Al}$ ratio. Contrib. Mineral. Petrol. 92, 471-480 (1986).

45. Doroshev, A. M., Brey, G. P., Girnis, A. V., Turkin, A. I. \& Kogarko, L. N. Pyrope-knorringite garnets in the Earth's mantle: Experiments in the $\mathrm{MgO}-\mathrm{Al}_{2} \mathrm{O}_{3}-\mathrm{SiO}_{2}-\mathrm{Cr}_{2} \mathrm{O}_{3}$ system. Russ. Geol. Geophys. 38, 523-545 (1997).

46. Klemme, S., Ivanic, T. J., Connolly, J. A. D. \& Harte, B. Thermodynamic modelling of Cr-bearing garnets with implications for diamond inclusions and peridotite xenoliths. Lithos 112, 986-991 (2009).

47. Nimis, P. et al. Crystallographic orientations of magnesiochromite inclusions in diamonds: what do they tell us? Contrib. Mineral. Petr. 174, 29-42 (2019). 
48. Howell, D. et al. $\mu$-FTIR mapping: distribution of impurities in different types of diamond growth. Diam. Relat. Mater. 29, 29-36 (2012a).

49. Howell, D. et al. Platelet development in cuboid diamonds: insights from micro-FTIR mapping. Contrib. Mineral. Petr. 164, 1011-1025 (2012b).

50. Breeding, C. M. \& Shigley, J. E. The "Type" Classification system of diamonds and its importance in gemology. Gems Gemol. 45, 96-111 (2009).

51. Boyd, S. R., Kiflawi, I. \& Woods, G. S. The relationship between infrared absorption and the A defect concentration in diamond. Philos. Mag. 69, 1149-1153 (1994).

52. Boyd, S. R., Kiflawi, I. \& Woods, G. S. Infrared absorption by the B nitrogen aggregate in diamond. Philos. Mag. 72, 351-361 (1995).

53. Leahy, K. \& Taylor, W. R. The influence of the Glennie domain deep structure on the diamonds in Saskatchewan kimberlites. Geol. Geofiz. 38, 451-460 (1997).

54. Taylor, W. R., Jaques, A. L. \& Ridd, M. Nitrogen-defect aggregation characteristics of some Australasian diamonds: Timetemperature constraints on the source regions of pipe and alluvial diamonds. Am. Mineral. 75, 1290-1310 (1990).

55. Miletich, R., Allan, D. R. \& Kuhs, W. F. High-pressure single-crystal techniques. Rev. Mineral. Geochem. 41, 445-519 (2000).

56. Angel, R. J., Bujak, M., Zhao, J., Gatta, G. D. \& Jacobsen, S. D. Effective hydrostatic limits of pressure media for high-pressure crystallographic studies. J. Appl. Crystallogr. 40, 26-32 (2007).

57. Scheidl, K. S. et al. Extending the single-crystal quartz pressure gauge up to hydrostatic pressure of $19 \mathrm{GPa}$. J. Appl. Crystallogr. 49, 2129-2137 (2016).

58. Angel, R. J. \& Finger, L. SINGLE: a program to control single-crystal diffractometers. J. Appl. Crystallogr. 44, 247-251 (2011).

59. King, H. E. \& Finger, L. W. Diffracted beam crystal centering and its application to high-pressure crystallography. J. Appl. Crystallogr. 12, 374-378 (1979)

60. Angel, R. J., Downs, R. T. \& Finger, L. W. High-temperature-high-pressure diffractometry. Rev. Mineral. Geochem. 41, 559-597 (2000).

61. Nickel, K. G. \& Green, D. H. Empirical geothermobarometry for garnet peridotites and implications for the nature of the lithosphere, kimberlites and diamonds. Earth Planet. Sci. Lett. 73, 158-170 (1984).

62. Taylor, W. R. An experimental test of some geothermometer and geobarometer formulations for upper mantle peridotites with application to the thermobarometry of fertile lherzolite and garnet websterite. Neues J. Mineral. Abh. 172, 381-408 (1998).

63. Nimis, P. \& Grütter, H. Internally consistent geothermometers for garnet peridotites and pyroxenites. Contrib. Mineral. Petrol. 159, 411-427 (2010)

64. Nimis, P., Goncharov, A., Ionov, D. A. \& McCammon, C. Fe ${ }^{3+}$ partitioning systematics between orthopyroxene and garnet in mantle peridotite xenoliths and implications for thermobarometry of oxidized and reduced mantle rocks. Contrib. Mineral. Petrol. 169, art. 6 (2015).

65. Pokhilenko, N. P., Pearson, D. G., Boyd, F. R. \& Sobolev, N. V. Megacrystalline dunites and peridotites: hosts for Siberian diamonds. Ann. Rep. Dir. Geophys. Lab. Carn. Inst. Wash., 11-18 (1991).

66. Hasterok, D. \& Chapman, D. S. Heat production and geotherms for the continental lithosphere. Earth Planet. Sc. Lett. 307, 59-70 (2011).

67. Day, H. W. A revised diamond-graphite transition curve. Am. Mineral. 97, 52-62 (2012).

\section{Acknowledgements}

The European Research Council is thanked for supporting this research (ERC Starting Grant No. 307322). GZ e MLM received funding from the European Research Council (ERC) under the European Union's Horizon 2020 research and innovation programme (grant agreement No. 714936 for the project TRUE DEPTHS to M. Alvaro).

\section{Author Contributions}

F.N. conceived the study. G.Z. and M.L.M. analysed experimental data for Ac139 and determined its P-V-T EOS. They also determined the isomeke for $\mathrm{MgCr}$. P.N. wrote all sections on geothermobarometry. B.P. collected the in-situ high-pressure data for Ac139. L.P. and A.L. collected FTIR data and characterized the diamond host using DIAMAP software. G.B.A., F.P., D.L. and L.S. reviewed the crystal chemistry of Ac139 and MgCr2 samples. A.M.L., N.V.S. and J.W.H. provided Ac139 and MgCr2 samples and reviewed the geology sections of the manuscript. All authors reviewed the manuscript.

\section{Additional Information}

Supplementary information accompanies this paper at https://doi.org/10.1038/s41598-019-48778-x.

Competing Interests: The authors declare no competing interests.

Publisher's note: Springer Nature remains neutral with regard to jurisdictional claims in published maps and institutional affiliations.

(c) (i) Open Access This article is licensed under a Creative Commons Attribution 4.0 International

License, which permits use, sharing, adaptation, distribution and reproduction in any medium or format, as long as you give appropriate credit to the original author(s) and the source, provide a link to the Creative Commons license, and indicate if changes were made. The images or other third party material in this article are included in the article's Creative Commons license, unless indicated otherwise in a credit line to the material. If material is not included in the article's Creative Commons license and your intended use is not permitted by statutory regulation or exceeds the permitted use, you will need to obtain permission directly from the copyright holder. To view a copy of this license, visit http://creativecommons.org/licenses/by/4.0/.

(c) The Author(s) 2019 